TITLE:

\title{
Temporal dynamics of infrasystem transition: The case of electricity system transition in Japan
}

$\operatorname{AUTHOR}(S)$ :

Mori, Akihisa

\section{CITATION:}

Mori, Akihisa. Temporal dynamics of infrasystem transition: The case of electricity system transition in Japan. Technological Forecasting and Social Change 2019, 145: 186-194

ISSUE DATE:

2019-08

URL:

http://hdl.handle.net/2433/254141

\section{RIGHT:}

(c) 2019. This manuscript version is made available under the CC-BY-NC-ND 4.0 license

http://creativecommons.org/licenses/by-nc-nd/4.0/; The full-text file will be made open to the public on 1 August 2021 in accordance with publisher's 'Terms and Conditions for Self-Archiving'; この論文は出版社版でありません。引用の際 には出版社版をご確認ご利用ください。; This is not the published version. Please cite only the published version. 


\title{
Temporal Dynamics of Infrasystem Transition: The Case of Electricity System Transition in J apan
}

\author{
Akihisa Mori \\ Graduate School of Global Environmental Studies, Kyoto University, 606-8501 Kyoto, Japan \\ Email: mori.akihisa.2a@kyoto-u.ac.jp (A. Mori)
}

\begin{abstract}
While a multi-level perspective on system innovation offers an analytical tool for explaining the role of landscape development and niche innovations in a transition of infrasystems toward sustainability, it has limitations in capturing hard-fought, inter- and intra-scalar contestations, and thus in exploring the role of governance structure and institution in a transition.

Against this background, this paper aims to explore how the temporal dimension have influenced market competition, power and interpretation, and the dynamics of electricity systems in a welfare state by examining Japan as a case study.

Our conclusions are as follows. First, periods of possessing and exercising power are important, both in terms of reinforcing the current infrasystem and in moving it toward a sustainable pathway. The longer that incumbents and their alliance possess and exercise power, the deeper that infrasystems can be embedded into society and the narrower the space created by landscape pressures becomes for developing niche innovators. Second, long time dominance of incumbents and its alliance in power enables them to capitalize on landscape pressures to reinforce them, realigning the currently unsustainable electricity system while to prevent sustainable niche innovations from sufficiently developed as reliable alternatives. Third, it can change the extent of feedback effects in policy instruments and institutional reform, weakening driving force for transition to sustainability.
\end{abstract}

\section{Keywords}

Electricity system, multi-level perspective, temporal dynamics, Japan

\section{Acknowledgement}

The author is grateful for the productive comments given by the internal and external reviewers. This paper is one of the results of a Japan-Netherlands bilateral joint research seminar entitled "Transition and its governance in Japan and the Netherlands," funded by the Japan Society for the Promotion of Science (JSPS). 


\section{Temporal Dynamics in Power Interpretation in Infrasystem Transition: The Case of Electricity System Transition in J apan}

\section{Introduction}

In a welfare state, the government plays a key role not only in security, but also in the protection and promotion of the economic and social well-being of its citizens in a capitalist or mixed economy. Through redistributionist taxation, the government collects funds to pay for these services, along with social security and health, civil and political liberties, goods and services and economic infrastructures that serve as the constituents of human well-being [1]. Over the decades, welfare states have cumulatively made huge investments in infrasystems, both in terms of physical components (infrastructure) and in terms of institutional settings and management components [2].

However, welfare states have not always invested in infrasystems with a focus on sustainability. A number of infrastructure projects have had adverse impacts on the environment and society. Further, the ongoing dynamics of infrasystems may also incrementally change them in unsustainable ways.

Shifting an ongoing pathway toward a sustainable one is not an easy task. All the transformation is replete with governance challenges, making infrasystem changes complex. A detailed analysis of the institutions and governance structures that influence the rules of competition between new actors and incumbents is required, as is an examination of factors affecting competition within existing regimes themselves.

Sociotechnical transition enables an analysis of long-term regime changes in infrasystems [3]. It emphasizes a pathway whereby radical innovation emerges in niches and breaks through and overthrows the existing regime in a specific way: (a) niche innovations build up internal momentum through learning processes, price/performance improvements and support from powerful groups, (b) changes at the landscape level create pressure on the regime, and (c) destabilization of the regime creates windows of opportunity for niche innovations [4] [5]. The multi-level perspective (MLP) of the sociotechnical transition enables a deeper understanding of the process of knowledge politics, political conflict and accommodation, bargaining and disciplining [6]. It defines a transition as a long-term fundamental change (irreversible, nonlinear, multi-leveled and systemic) in the culture (mental maps, perceptions), structures (formal institutions and infrasystems) and practices (use of resources) of a societal system [7][8], describing that change as the outcome of multi-dimensional interactions between radical niche innovations, an incumbent regime and an external landscape [9].

Meanwhile, there remains a black box for determining when a transition will take place, at what speed and what its impact will be. First, landscape pressures bring about different outcomes on the 
transition path according to whether or not there are fully developed niche innovations. Second, neither landscape pressure nor sufficiently developed niche innovations can push an infrasystem toward any type of transition pathway unless niche innovators significantly gain ground in the overall competition. Third, the alignment of necessary developments does not always occur simultaneously at the three levels. This is especially true of large infrasystems such as those in the electricity sector (hereinafter, electricity systems), where sunk investments and high entry barriers are important [10]. Such systems are strongly path dependent and deeply embedded in society in terms of norms, values, laws, modes of governance, social relations and culture. For these reasons, large systems are prone to technological and institutional lock-in. Finally, incumbents have comparably large power and resources to reproduce existing paradigms and structures to reinforce the current socio-technical regime when faced with landscape pressure and emergence of niche innovations. Insufficient pressure by market competition gives them space and resources to protect vested interests.

These factors make infrasystem transitions hard-fought inter- and intra-scalar contestations between old and new institutions, agents and technologies [11], posing inherent limitations on rapid change [6].

While a multi-level perspective on system innovation offers an analytical tool to explain the role of landscape development and niche innovations in the transition to sustainability, it is limited in capturing such contestations, and thus in exploring the role of governance structure and institutions in the transition. To explore their role, it is indispensable to add three fundamental concepts in governance structure and institutions-market competition, power and interpretation-to the MLP model. Given the pass dependency of the infrasystem and the embedding in society, thus long-term nature of sustainability transition, the speed at which a transition can take place-its timing, or temporal dynamics - is a critical element of consideration [12]. When taking temporally dynamics into account, the evidence may not always support the predominant view that niche innovators will evolve to completely dominate a landscape.

This paper aims to explore how the temporal dimension have influenced market competition, power and interpretation, and the dynamics of electricity system in a welfare state in the end, when faced with landscape pressures and emergence of niche innovations. It pays special attention on how period of power possession and exercise associates with the power relations and dynamics between 'power to change' and 'power to maintain.'

We employ a long-term perspective similar to prior examples in the literature [10][13], taking Japan as a case. Japan has been struggling over which pathway to take-a nuclear-centered or renewable-centered system - both of which are pathways toward a low-carbon society.

The remainder of this paper is organized as follows. Section 2 surveys the literature to establish 
an analytical framework and Section 3 describes our methodology. Using this framework, Section 4 first identifies the typology of transition pathways by period, and analyzes changes in market competition, power and interpretation and the transition pathway of electricity system in Japan. Section 5 discusses the role of market competition, power and interpretation in the research of electricity system transition. Section 6 presents our conclusions.

\section{Analytical framework}

To evaluate how the types and timing of landscape pressure on regimes and the state of niche developments generate different outcomes on the transition path, the MLP model examines the typology of transition pathways [4]. Specifically, it classifies the transition of a country's electricity system into three pathways: transformation, de-alignment and re-alignment, and reconfiguration [10][14]. Transformation is characterized by moderate external pressure at the landscape level or from outsider social groups, while niche innovations such as nuclear and renewable energy have not yet been sufficiently developed. The demonstration of viable alternatives by an outsider may change the perceptions of regime insiders such as incumbent electric power companies and the government and lead to a reorientation of activities. However, innovations are still limited to a niche and are incapable of reorienting the systemic configuration. Sufficient network capacity, system-balancing facilities and strong demand management are required to stabilize a hybrid system. In de-alignment and re-alignment pathways, the landscape change is so divergent, large and sudden that the regime experiences major internal problems, collapse, erosion and de-alignment. However, as there is no stable niche innovation present, multiple embryonic niche innovations emerge, co-exist and compete for a prolonged period. Eventually, one niche innovation gains momentum and becomes dominant. In the reconfiguration pathway, the regime adopts certain niche innovations into the system as add-ons or component substitutions because the niche innovations have already developed by the time the regime faces external pressure. The adoption of niche innovations will gradually influence the reconfiguration of the basic architecture and change some guiding principles, beliefs and practices.

To apply this typology in electricity system, sustainable transition pathways can be described as follows [10]. In the transformation pathway, electric power companies pay more attention to renewable electricity, but fossil fuel and nuclear power plants remain important. The companies make necessary adaptations but keep the existing system intact. Renewable energy technology is still limited to a niche and incapable of reorienting the configuration of the industry. Sufficient network capacity, system-balancing facilities and strong demand management are required to stabilize the hybrid system.

In the de-alignment and re-alignment pathways, the regime actors lose faith in the usual 
solutions, leading to a period of uncertainty about the direction of the system and experimentation with multiple niche innovations and more local- or region-based systems. Niche innovators are no longer confined to renewable electricity generators and manufactures; local electric power companies, consumer cooperatives, housing associations and municipalities appear as niche innovators, leading to the emergence of a new regime. The guiding principle is a strong preference for distributed generation and load balancing.

In the reconfiguration pathway, external landscape pressures advance the scaling up of renewable electricity generators, requiring stronger transmission grids such as a region-wide super-grid. The new guiding principles, beliefs and practices partially return to the more top-down control and management philosophies that were dominant before the landscape pressures.

This typology, however, has limitations in analyzing how institutions and governance structures mediate the connections between landscapes, socio-technical regimes and niche innovations [15]. Three fundamental concepts are useful in analyzing their role as they enable dynamic analysis of political, economic and social factors that critically affect the typology of transition pathways [16]. The first concept is market competition. Niche innovators must improve their performance or price in a relatively short period to obtain a certain market share so that consumers can expect further improvements and eventually winning the competition.

The second concept is power. Changes arise from conflicts, power struggles, contestations, lobbying, coalition building, and bargaining. Power exercise is classified into three typologies: innovative, constitutive and transformative exercises [17]. Innovative power is defined as the capacity of actors to create or discover new resources, making actors less dependent on other existing resources. Constitutive power is defined as that of actors constituting the distribution of resources by establishing, enforcing and reproducing existing structures and institutions. Transformative power is defined as the capacity to transform the distribution of resources, not just in terms of redistributing or replacing old with new resources, but specifically in terms of changing how resources are distributed. This includes the development of new institutions and structures on resource distribution. While innovative and transformative power generates the antagonistic power dynamics and relations that are necessary conditions for transition, constitutive power produces synergetic dynamics that 'absorb' innovative and transformative potentials, thus bringing counteractive results to transformation [18]. For innovative power to gain sufficient bargaining power, it is useful to concentrate on alliances between those who have different motives or priority but is willing to join the supporting community, and with transformative potentials [19]. Transition to sustainability is likely to take several years or decades even if empowerment of innovative power leads to changes in the formal rules, as dominant ideas change only slowly, and constitutive power capitalizes on the resources to swing back the policy instruments and hierarchy of policy objectives. 
Thus it is also indispensable for innovative power to make the alliance politically sustained for a long time [20].

The third concept is interpretation. Niche innovators and incumbents struggle not only over power and the changing of formal rules, but also over the creation of rules, norms and cognition. They may propagate their interpretation of rules at a massive scale across society to enhance their bargaining power. Such an interpretation gradually turns into a deep structure and is taken for granted, as it becomes more widely accepted in society. Incumbents may reposition themselves and restructuring coalitions when tensions occur within the dominant interpretation and emerging interpretations undermine the dominant one [21].

\section{Methodology}

Placing the MLP of sociotechnical transition as the basis of its analytical framework, this paper first employs the typology of transition pathways to evaluate how landscape pressures on regimes and the state of niche development have resulted in a specific transition pathway in the Japanese electricity system. Next, it employs the three concepts of market competition, power and interpretation to analyze how governance and institutional structures mediate the connections between landscapes, socio-technical regimes and niche innovations in the case of Japan, with special focus on alliance created and reinforced by innovative and constitutive power. Given that transition to sustainability is likely to take long period of time, and alliance is likely to be created in response to disruptive landscape pressures, we add temporal dimension of power relations and dynamics to see interaction between these power on the one hand, and governance structure and institutions on the other. Our analysis makes use of the existing literature, government reports, energy statistics and newspaper articles from Japan.

\section{Case study of electricity system transition in Japan}

Japan has gone through several disruptive landscape pressures that affected market competition, power and its relation and interpretation, and then the electricity system (Table 1).

Our analysis starts in 1973 when Japan faced an oil crisis and encountered losses in the environmental court that imposed stringent environmental regulations. While a variety of niche innovations, including renewables, emerged and were stimulated, the government reinterpreted the concept of energy security to choose nuclear power as a key alternative to oil, directing the incumbent private electric power companies to develop nuclear power plants. This changed market competition among the type of electricity and power relations between the government and incumbent electric power companies.

The second major landscape pressures occurred in the late 1990s, which featured liberalization 
of the electricity market and the emergence of a global climate change regime. While this landscape pressure opened the window for renewables and independent power producers (IPPs) to emerge, it also reinforced the current electricity system.

The third period began with the 2011 Fukushima nuclear disaster, which caused rotational blackouts, suspension of all nuclear power plants and a 25\% electricity tariff hike. This destabilized the current system to open a window for massive deployment of renewable energy. The Democratic Party of Japan (DPJ)-led government attempted to go further to accelerate the phase-out of the nuclear power by placing an integrative decision making process and mobilizing society.

The fourth period began in late 2012, when the Liberal Democratic Party (LDP) regained power. While it revised the Electricity Business Act to accelerate a nationwide system balancing of supply and demand, unbundling and liberalizing the market, it held back the renewable energy boom, impairing their market competitiveness by pushing for re-commissioning of nuclear power plants, rapidly dropping electricity purchasing prices under a feed-in tariff and endorsing incumbent electric power companies' refusal of grid connections.

Table 1 Brief History on Landscape Pressures and Policy Changes

\begin{tabular}{|l|l|}
\hline \multicolumn{1}{|c|}{ Year } & \\
\hline 1970 & Revision to the Basic Environmental Act and Air Pollution Control Act \\
\hline 1973 & $\begin{array}{l}\text { Enactment three laws to impose electricity surcharge so that the government provided } \\
\text { subsidy for local government that accepted location of power plants }\end{array}$ \\
\hline $1973-4$ & The first oil crisis \\
\hline 1974 & Enactment of the Pollution-related Health Damage Compensation Law \\
\hline $1979-80$ & The Second oil crisis, followed by the enactment of the Energy Conservation Act \\
\hline \multirow{2}{*}{1995} & $\begin{array}{l}\text { Independent power producers (IPPs) are allowed to join in the generation market (power } \\
\text { producer and suppliers (PPSs) in 2000) }\end{array}$ \\
\hline 1997 & Agreement to the Kyoto Protocol (made effective in 2005) \\
\hline 2002 & Enactment of the renewable portfolio standard (RPS) Law \\
\hline 2004 & Smaller PPSs are allowed to join the retail market \\
\hline \multirow{2}{*}{2009} & The DPJ won the general election and gained political power \\
\cline { 2 - 3 } & $\begin{array}{l}\text { Commitment to a 25 percent reduction of GHG emissions by 2020 compared to the } 1990 \\
\text { level }\end{array}$ \\
\hline \multirow{2}{*}{2011} & The Fukushima nuclear disaster \\
\hline \multirow{2}{*}{2012} & Enactment of the Renewable Energy Act that mandated a feed-in tariff \\
\cline { 2 - 3 } & The LDP came back to the government \\
\hline
\end{tabular}




\begin{tabular}{|l|l|}
\hline 2013 & Revision to the Electricity Business Act for electricity system reform \\
\hline 2014 & Cabinet decision on the Fourth Strategic Energy Plan \\
\hline
\end{tabular}

Source: Author.

\subsection{Transition pathways}

\subsubsection{Oil crises and stringent environmental regulations (1973-97)}

Two oil crises and stringent environmental regulations in the 1970s destabilized the socio-technical regime that featured regionally monopolized oil-based power production systems with increasing levels of consumption. Subsequent oil crises and OECD restrictions on the use of oil for thermal power plants forced Japan to halt its increasing use of oil-fired power plants that had provided cheap and stable electricity to industry. Stringent environmental regulations forced electric power companies to invest in fuel gas desulphurization and fuel gas denitrogenization. Meanwhile, no niche innovations had been sufficiently developed at that time for modifying the use of oil-fired thermal power.

This created a space for the emergence of multiple niche innovations, including waste heat recovery systems, higher efficiency gas turbines, liquefied natural gas (LNG), nuclear power and renewable energy. The government supported their emergence by enacting the Energy Conservation Law, establishing technical standards and providing research grants to a variety of niche innovators [22] and subsidies for diffusion. This resulted in the development and wider deployment of many energy-efficient production technologies. In the meantime, the LDP, the ruling party for most of the post-World War II period, together with the Ministry of International Trade and Industry (MITI, now the Ministry of Economy, Trade and Industry (METI)), encouraged incumbent private electric power companies to build and operate nuclear power plants, and initiated a closed nuclear fuel cycle.

In the end, the electricity system was re-aligned as one featuring a combination of LNG and nuclear-based power production, as demonstrated by a major change in the fuel mix (Figure 1). Oil-fired generation hit its peak in 1978 and has declined thereafter. By contrast, gas and nuclear power generation rapidly increased during this period, and an alliance that supported nuclear (hereafter nuclear alliance) was created.

Figure 1. Electricity Production in J apan by Fuel Source, 1952-2013 


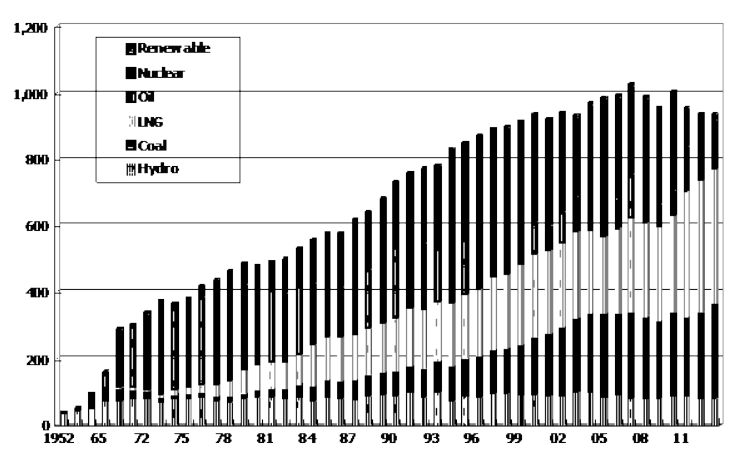

Source: Author compilation of data in [23][24].

\subsubsection{Partial market liberalization and climate change (1998-2010)}

In response to increasing criticism from outside social groups and industrial associations united against higher electricity tariffs, the government decided to launch a phased liberalization of the electricity market with the aim of enhancing market dynamism and efficiency. In response to an emerging international framework on climate change, in the Kyoto Protocol the Japanese government committed to a 6 percent reduction in greenhouse gas (GHG) emissions from the 1990 level by 2012. In 2009, the government further pledged a 25 percent reduction from the 1990 level by 2020, It planed to increase nuclear power plants and renewable energy as a way of attain these targets. However, the Renewable Portfolio Standard (RPS) Act mandated the incumbent power suppliers to supply only 1 percent of total electricity generation despite METI's initial proposal of 3 percent target.

These policy responses have increased the number of independent power producers (IPPs) and power producer and suppliers (PPSs). Some IPPs and PPSs, as well as municipalities, launched renewable energy projects that increased the share of renewable energy to 1 percent of total electricity consumption in 2007 (Figure 1).

However, IPPs held only a 3.6 percent share of total provision [25], and the share of renewable energy remained less than 1 percent in 2011 [23]. Increased electricity demand was mostly satisfied by new LNG-fired and nuclear power plants built through the investment of incumbent electric power companies [26]. To attain the 25 percent emissions reduction pledge the government released the 2010 Strategic Energy Plan that would establish nine new nuclear power plants and increase the share of nuclear power to 53 percent of total power generation in 2030. This plan was put forth even though the 2000s saw several accidents that led to stagnation in nuclear power development.

In this regard, market liberalization and emergence of global climate governance only slightly moved the current electricity system toward the transformation pathway. 


\subsubsection{The Fukushima nuclear disaster and aftermath (2011-12)}

The DPJ-led government capitalized on the Fukushima nuclear disaster to replace the RPS with a feed-in-tariff, and broadened its scope to include all renewable electricity. It also mandated that incumbent electric power companies purchase all renewable energy generated for a certain number of years at a price that ensured a certain profit margin to renewable power producers. To change the hierarchy of policy objectives in the energy sector, the DPJ-led government created the Energy and Environment Council in the Prime Minister's Office and adopted an innovative decision-making process that featured integrated decisions based on energy and climate plans as well as deliberative opinion polls. This opened a window for renewable energy producers to develop and gain ground in the competition under the current electricity system.

With this change in formal rules, a variety of niche innovators emerged, including renewable independent power providers, gas companies that supply fuel cells, agricultural cooperatives that provide biomass, housing companies, and municipalities. Many companies invested in large-scale solar projects, and many households installed rooftop solar photovoltaic (PV). A profitable purchase price setting enabled developers to procure solar PV cells and modules made by Japanese manufacturers, who regained some of the global market share ${ }^{1}$ [27]. There was a significant increase in solar power. Solar power capacity increased rapidly from $20 \mathrm{MW}$ in 2011 to $30 \mathrm{MW}$ in 2013, and its share of total capacity jumped from 1.4 percent to 2.2 percent during this period [28].

In sum, the Fukushima nuclear disaster in 2011 caused major regime tensions, destabilizing the electricity system and opening a window of opportunity for massive diffusion of renewables. The electricity system was moved toward the transformational pathway that accepted renewable energy massively.

\subsubsection{The LDP returns to power (2013-Present)}

The LDP-led government in principle accepts deployment of renewable energy. The 2014 Strategic Energy Plan included an increase in renewable energy and energy conservation and a decrease in nuclear energy. It predicts that renewable energy will make up between 22 and 24 percent of the total electricity supply in 2030, compared with 2.2 percent in 2013 [24]. Premised on the safety of nuclear operations, the plan cites the promotion of nuclear reactor fuel cycles as a measure to attain energy security.

In reality, however, it takes a harsh stance to renewable energy. First, it squeezes the profits of renewable IPPs and PPSs, for it regards most of them as rent seekers wanting to profit from higher

${ }^{1}$ Concerned about the international competitiveness of the Japanese renewable energy manufacturing industry [53], the government emphasized green innovation through a range of measures such as including renewable energy in the 2009 National Growth Strategy and the 2010 Strategic Energy Plan and instituting a higher feed-in tariff for solar power. 
purchase prices amid globally declining solar panel and module prices. Second, it posed no sanctions against incumbent electric power companies for their refusal to grid connections with renewable IPPs, despite that it is proven to be technologically feasible to include variable renewables by 25-40 percent with current level of flexibility in electricity system [29]. METI justifies no sanction for the reason that no act mandated them to increase network and system-balancing capacity for high inclusion of variable renewables. However, the LDP-led government is suspected to simply want to reduce their burden accompanied by the curtailment, because they have to pay compensation to renewable energy producers for the loss caused by curtailment if they request curtailment for more than 30 days [30].

In the meanwhile, the LDP-led government encouraged accelerating the process for re-opening nuclear power plants. It also advanced the unbundling and liberalization of the market.

In sum, the LDP-led government accepts the transition along the transformational pathway, but as far as the transition does not disturb the reopening of nuclear power plants. The LDP-led government does not actively take measures and reform institution that move the system toward de-alignment and re-alignment or reconfiguration pathway.

\subsection{Changes in market competition, power and interpretation}

\subsubsection{Oil crises and stringent environmental regulations}

The oil crises and stringent environmental regulation in the 1970s changed the interpretation of energy among the government, incumbent electricity power companies and consumers: they shared the new interpretation that they could no longer enjoy cheap oil and that alternatives had to be found to secure a stable energy supply. This interpretation prompted the LDP and MITI to help incumbent electric power companies import LNG, encourage them to open new nuclear power plants, initiate a nuclear fuel cycle and provide subsidies for niche innovations. Through massive sponsor fees and research grants, the mass media and researchers have been conditioned to promote the safety and benefits of nuclear power [31], despite scant progress in the development of new nuclear power plants.

These government actions changed the market competition among sources of energy. Earmarked subsidies for new nuclear power plants helped incumbent electric power companies quell local protests, which reduced transaction costs. Government initiatives toward a nuclear fuel cycle enabled them to save backend costs. These measures lowered nuclear power generation costs, motivating them to build many new nuclear power plants for profit. As nuclear power became the decisive factor for electricity pricing, incumbents ceased market competition. On the other hand, government subsidies for renewable energy targeted installation instead of deployment. They helped Japanese manufactures to develop solar PV and gained massive share in the world market, 
but did not increase the share of renewable energy in Japan.

Government pro-nuclear policy in this period constructed and reinforced an alliance among the LDP, central and local government bodies, incumbent electric power companies, industrial association and nuclear power reactor manufacturers. Incumbent electric power companies became dependent on the LDP and MITI for gaining local consent for locating nuclear power plants. Earmarked subsidies helped expand the nuclear alliance that ultimately involved local governments and community leaders in the nuclear power plant sites [32], as funds could be used for infrastructure development in these localities. Industrial associations remained supportive of LDP policy as long as it secured a stable supply of cheap energy. Nuclear power reactor manufacturers joined in the alliance in need of sustaining their business because they are not allowed to engage in military applications of nuclear power [33]. Their participation further empowered the alliance, as they are Japanese leading manufacturers that have political and economic power.

\subsubsection{Partial market liberalization and climate change}

Despite its limited range, market liberalization affected competition. Incumbent electric power companies began to establish power plants across the areas they had provided services monopolistically to compete with each other. IPPs and PPSs renovated exiting coal-fired power plants or built large, highly efficient ones to enter the market, as coal remains among the cheapest sources of power production (Figure 1) [34]. In response, incumbent electric power companies invested in large, highly efficient coal-fired power plants to maintain competitiveness in their own market, while ceasing cross-area cooperation that enabled regional balancing that helps competitors.

The Kyoto Protocol changed market competition in favor of non-fossil fuels such as renewable and nuclear energy. PPSs began to deliver renewable electricity to environmentally conscious customers under the RPS.

Meanwhile, repeated technical troubles at nuclear power plants and fast breeder reactors caused fierce local protests, which led to long operational delays ${ }^{2}$. This led to more stringent safety regulations, which raised the cost of operation. A committee under METI unveiled that the estimate cost of a closed nuclear fuel cycle was much higher than that of direct disposal.

In response, incumbent electric power companies worked hard on to capture MITI and the LDP and the Nuclear Safety Commission by taking advantage of asymmetric information and by hiring their retired officers at higher compensations. Capitalized on the rising energy prices in the

${ }^{2}$ It was not until 1993 that the government started construction of a reprocessing plant with a higher capacity, coupled with a low-level radioactive waste site and a temporary high-level waste site [54]. The reprocessing plant is still under test operation as of the end of 2015. 
mid-2000s, they tamed them to shift their policy focus from liberalization to energy security [35]. The LDP-led government released its Nuclear Initiative Plan that aimed for expansion of the operation of nuclear power plants and the development of a closed nuclear fuel cycle. The plan called for active export of nuclear power plants, aiming to revitalize Japanese reactor manufactures, which led to empowerment and increase in vested interests of the nuclear alliance. METI relegated officials who initiated market liberalization and feed-in-tariffs for renewable energy to implement a RPS instead of a feed-in-tariff in 2003. In addition, it succeeded in keeping the share of renewable energy that incumbents had to supply by 1 percent, which increased uncertainty of profitability for renewable energy producers and discouraged their investment.

Incumbent electric power companies have also spent massive financial resources to tame mass media and research communities to highlight the side effects of the liberalization and renewable energy. Citing the 2001 electricity crisis in California, they justified imposition of high imbalance charges and wheeling charges [36]. They also propagated possible side effects of renewable energy such as tariff hikes and destabilization of the electricity supply. At the same time, they defined advantages of nuclear power as safe, clean and renewable energy that contributed one third of power supply and propagated them through media. It has even increased spending for propaganda to tame media especially after faced with fierce local protests and increasing number of accidents at nuclear power and reprocessing plants. Their spending amounted to at least JPY 2.4 billion (US\$ 22 million) during 1970-2011 ${ }^{3}$ [37]. As a result, 60 percent of the people expressed a favorable opinion to the development of nuclear power, and 19 percent to the hold of the current state in the public opinion survey in 2009 [38].

They went further to exert power exercise to block development of institutions for renewable energy. They convinced METI to delay the development of spot and real time market, independent authority and institutions that ensure fair access to grid and transmission network. This made it difficult for IPPs and PPSs to offer competitive pricing in the market ${ }^{4}$. IPPs and PPSs gained only 3.5 percent in the power supply by 2010 [39]. They also convinced METI to mandate renewable energy supply only a 1 percent of power supply, and to abandon a subsidy program for installing rooftop PV systems in exchange of implementation of the RPS. This dampened the prospects of Japanese PV module and cell manufacturers in Japanese market, losing competitiveness in the global market in the end.

In sum, partial market liberalization and climate change did not change the playing field in the market competition and people's interpretation of the current electricity system. The nuclear

${ }^{3}$ Ironically, these spending have been financed through electricity tariff charged on consumers who are given little choice of electricity under the regionally monopolized, vertically integrated supply system of electricity.

${ }^{4}$ Only five small industrial plants established IPPs to begin coal-fired power generation [30]. 
alliance capitalized on landscape pressures to reinforce their power relation against their opponents by taming media to join in and to defend the current regionally monopolized, nuclear-centered power supply system, which had provided the alliance for financial resources to keep and reinforce their power.

\subsubsection{The Fukushima nuclear disaster and its aftermath}

The Fukushima nuclear disaster changed the public's interpretation of the electricity system. On the one hand, people reinterpreted nuclear power as being tremendously risky, leading to loss of confidence in the current nuclear power policy [40]. This prompted the DPJ-led government to suspend operation of all nuclear power plants until a reorganized and more independent, neutral and powerful Nuclear Regulation Authority approved their renewed operation based on an updated regulatory standard [41]. They also reinterpreted renewables and conservation as much more preferable alternatives to nuclear power in terms of energy independence, disaster risk reduction and climate change mitigation ${ }^{5}$.

Market competition among the type of electricity was changed with the suspension of nuclear power plants and a feed-in-tariff for renewable energy. Massive investments were made in solar power that required shorter gestation periods and that were perceived to be of lower risk in comparison with other renewable options. At the same time, both incumbents and IPPs invested in coal power as coal power proved to be the cheapest under the suspension of nuclear power.

The disaster also altered power relations between renewable energy producers and the nuclear alliance, and within the latter. A feed-in tariff attracted a number of companies to join in the market as renewable IPPs and PPSs, creating an alliance that support renewable energy (hereafter renewable alliance) and pressuring the government to set purchasing prices that levelled the economic and regulatory playing field between renewable energy and fossil fuels (Table 1). Perceiving higher profits and low risk under the feed-in-tariff, financial institutions started invested in renewable energy projects, thereby joining in the alliance.

The bail-out of the Tokyo Electric Power Company (TEPCO), which operated the Fukushima nuclear power plants, and the most influential incumbent, loosened the nuclear alliance. Incumbent electric power companies could not control media's report on the damage and victims of the disaster, and possible risks of nuclear power any more, while had no choice but to stop propagation. METI was released from its capture, becoming a transformative power to advance unbundling of a vertically integrated power supply and further market liberalizations that incumbent electric power companies had so far refused [36]. The DPJ-led government went on to revise the Strategic Energy Plan to accelerate the phase-out of nuclear power. It adopted energy-climate integrated 
policy-making process and implemented a deliberative opinion poll to mobilize people's incredulity regarding nuclear safety. It succeeded to gain a majority of support for the future nuclear phase-out option and described it in the draft integrated strategic plan.

The renewable alliance, however, generated synergy power when it mentioned to future phase-out of nuclear power plants. Phase-out deprives local benefits that have been created in exchange of accepting location of nuclear power plants and the reprocessing facilities, such as employment, infrastructure development and budgetary support. It also leads to the abolishment of a closed fuel cycle, which would not only saddle incumbent electric power companies with an additional financial burden [42], but create conflict with local governments that had accepted reprocessing facilities on the condition that they would not be used for final disposal [43]. It also provoked conflict over spent fuel with the United Kingdom, to whom Japan had contracted out pre-treatment of its nuclear fuel, as well as with the United States, which had permitted Japan to keep spent nuclear fuel under a bilateral nuclear cooperation agreement that prohibits Japan from processing it for military use. Amid fierce advocacy against the nuclear phase-out option by the United States [44], the DPJ-led government failed to find an alternative or address the closed nuclear fuel cycle in a deliberative opinion poll. Coupled with increasing incredulity toward the DPJ-led government, these negative feedback effects made the DPJ-led cabinet indecisive on the new integrated strategic plan.

In sum, the Fukushima nuclear disaster loosed the nuclear alliance, making people reinterpret nuclear power and the regionally monopolized, nuclear-centered power supply system, and opened a window for massive deployment of renewable energy. This pushed the DPJ-led government to implement a feed-in-tariff that reshapes the market in favor of renewables. However, the electricity system had been so deeply embedded within society and incorporated into the power relations with the UK and USA that the DPJ-led government was incapable of moving the current electricity system to go beyond the transformation pathway within two years of government control amid declining party support by the public.

Table 1. Purchase Price and Period under the Feed-in-Tariff for Renewable Energy

\begin{tabular}{|c|c|c|c|c|c|c|c|}
\hline \multirow[b]{2}{*}{ Type } & \multirow[b]{2}{*}{ Size } & \multirow{2}{*}{$\begin{array}{l}\text { Purchase } \\
\text { Period } \\
\text { (years) }\end{array}$} & \multicolumn{5}{|c|}{ Purchase Price (JPY/kWh), Excluding VAT } \\
\hline & & & 2012 & 13 & 14 & $\begin{array}{c}\text { Apr-Jun } \\
2015\end{array}$ & $\begin{array}{l}\text { July } 15 \\
\text {-Mar } 16\end{array}$ \\
\hline \multirow[t]{2}{*}{ Solar } & Over $10 \mathrm{~kW}$ & 20 & 40 & 36 & 32 & 29 & 27 \\
\hline & Below 10kW (with & 10 & $42 *$ & $38 *$ & $37 *$ & 35 & 35 \\
\hline
\end{tabular}




\begin{tabular}{|c|c|c|c|c|c|c|c|}
\hline & output controller) & & & & & & \\
\hline & $\begin{array}{l}\text { Below 10kW (without } \\
\text { output controller) }\end{array}$ & & & & & 33 & 33 \\
\hline & $\begin{array}{l}\text { Below } 10 \mathrm{~kW} \text { (Double } \\
\text { generation) }\end{array}$ & 10 & $34 *$ & $31 *$ & $30 *$ & $30 *$ & $30 *$ \\
\hline Wind & Over $20 \mathrm{~kW}$ & 20 & 22 & 22 & 22 & 22 & 22 \\
\hline & Below $20 \mathrm{~kW}$ & 20 & 55 & 55 & 55 & 55 & 55 \\
\hline & Off-shore wind power* & 20 & - & - & 36 & 36 & 36 \\
\hline Geothermal & Over 15,000 kW & 15 & 26 & 26 & 26 & 26 & 26 \\
\hline & Below 15,000 kW & 15 & 40 & 40 & 40 & 40 & 40 \\
\hline Biomass & $\begin{array}{l}\text { Methane from biomass } \\
\text { fermentation }\end{array}$ & 20 & 39 & 39 & 39 & 39 & 39 \\
\hline & $\begin{array}{l}\text { Wood biomass from } \\
\text { chips and tree thinning } \\
\text { over } 2000 \mathrm{~kW}\end{array}$ & & & & & 32 & 32 \\
\hline & $\begin{array}{l}\text { Wood biomass from } \\
\text { chips and tree thinning } \\
\text { over } 2000 \mathrm{~kW}\end{array}$ & & & & & 40 & 40 \\
\hline & General wood biomass & 20 & 24 & 24 & 24 & 24 & 24 \\
\hline & $\begin{array}{l}\text { Construction material } \\
\text { waste }\end{array}$ & 20 & - & 13 & 13 & 13 & 13 \\
\hline & $\begin{array}{l}\text { General waste and other } \\
\text { kinds of biomass }\end{array}$ & 20 & - & 17 & 17 & 17 & 17 \\
\hline $\begin{array}{l}\text { Small hydro } \\
\text { electric }\end{array}$ & $\begin{array}{l}\text { Over } 1,000 \mathrm{~kW} \text { below } \\
30,000 \mathrm{~kW}\end{array}$ & 20 & 24 & 24 & 24 & 24 & 24 \\
\hline & $\begin{array}{l}\text { Over } 200 \mathrm{~kW} \text { below } \\
10,000 \mathrm{~kW}\end{array}$ & 20 & 29 & 29 & 29 & 29 & 29 \\
\hline & Below $200 \mathrm{~kW}$ & 20 & 34 & 34 & 34 & 34 & 34 \\
\hline $\begin{array}{l}\text { Small } \\
\text { hydroelectric }\end{array}$ & $\begin{array}{l}\text { Over } 1,000 \mathrm{~kW} \text { below } \\
30,000 \mathrm{~kW}\end{array}$ & 20 & - & - & 14 & 14 & 14 \\
\hline $\begin{array}{l}\text { using } \\
\text { existing }\end{array}$ & $\begin{array}{l}\text { Over } 200 \mathrm{~kW} \text { below } \\
10,000 \mathrm{~kW}\end{array}$ & 20 & - & - & 21 & 21 & 21 \\
\hline $\begin{array}{l}\text { waterways** } \\
*\end{array}$ & Below $200 \mathrm{~kW}$ & 20 & - & - & 25 & 25 & 25 \\
\hline
\end{tabular}


* VAT included.

** Plants that require access by vessels in construction, operation, and maintenance.

*** Plants that renovate electrical equipment and hydraulic iron pipes on existing waterways.

Source: [45][46].

\subsubsection{LDP's return to power}

After the LDP won the general election at the end of 2012, the nuclear alliance revived their power and exercised it to accelerate reoperation of the suspended nuclear power plants and to discourage renewable energy, niche innovators and IPPs in general.

First, METI and the LDP exerted political influence on the human resource management of the Nuclear Regulation Authority so that its staff would not be too strict and prohibitive when conducting earthquake risk assessments. Second, they decided to unbundle and liberalize the gas market. This enabled incumbent electric power companies to retard enter the gas market while to threaten the incumbent, regionally monopolized gas companies to retard entering the electricity market as well as joining the renewable alliance. Third, METI has pressured the Purchasing Price Assessment Committee to reduce privileged tariffs for renewables (Table 1). Seeing that the high purchase price of renewable energy did not benefit Japanese manufacturers ${ }^{6}$ and harmed the vested interests of the incumbent electric power companies, the LDP and METI claimed that balance is required between an increase in renewable energy and increased renewable energy surcharges that consumers must bear [43]. Fourth, METI mandated that all electricity suppliers reveal carbon content, while recommending that they reveal the fuel sources of their supplied electricity. This was implicitly aimed at chipping off the competitiveness of IPPs and PPSs that supply electricity generated at coal power by encouraging climate conscious customers to avoid choosing them.

To restore the previous public interpretations and gain support from industrial customers, the nuclear alliance spent massive resources to propagate side effects of the suspension of nuclear power plants, exaggerating the adverse impacts on economic growth and trade balance. It also discredited renewables with the public. METI uncovered number of "disguised” solar power providers that capitalized institutional failure to gain windfall profits. As METI admitted solar power producers to sell solar power at the price of the year of subscription instead of that of start operation, huge number of would-be producers rushed into subscription, prospecting fall down of the solar PV module and cell prices ${ }^{7}$. Incumbent electric power companies mobilized the media to propagate the message that such a massive deployment of solar power would result in higher

6 “Dark clouds hang over the feed-in tariff for renewable energy,” Sankei Shinbun, September 12, 2012 (in Japanese)

7 "Only ten percent of renewable contractors have actually generated solar power," Nikkei Shinbun, December 15, 2013 (in Japanese) 
consumer tariff, citing recent tariff hikes in Germany ${ }^{8}$. METI endorsed these opinions by issuing a warning that electricity prices would become significantly higher [47]. Highlighting lower price as a benefit of market liberalization, the LDP and METI attempt to redirect people's concern toward price and away from renewables.

Nonetheless, renewables are perceived as a high return, low risk investment for financial institutions amid the global price collapse in renewable energy equipment. Renewable energy, especially “mega-solar” power projects kept attracting investments massively.

The nuclear alliance went further, directly intervening in the market to weaken the competitiveness of renewables. Half of the regionally monopolized incumbent electric power companies refused grid connection applications from all renewable energy producers, insisting that they would receive levels of renewable electricity exceeding the grid capacity if all approved renewable electricity projects started operation. In addition, they refused investment in cross-regional transmission that would accept renewable energy as a variable power source [48], while at the same time reserving the majority of transmission capacity for their own use $\mathrm{e}^{9}$. METI endorsed their decision, insisting that the incumbent electric power companies are obliged in stable supply while renewable IPPs would destabilize the power supply system, noting that solar power had already been approved for more than the targeted capacity described in the 2014 Strategic Energy Plan [49]. When grid connection applications resumed, METI allowed incumbent electric power companies to refuse grid connections whenever renewable energy would be supplied in excess of the grid capacity without compensation and regardless of the scale of the renewable energy generators.

These measures made revenue of renewable IPPs and PPs unpredictable, which discouraged financial institutions from making investments and providing loans [49].

In sum, faced with rapid deployment of renewables, especially solar power, the nuclear alliance exercised its revitalized power to weaken the market competitiveness and bargaining power of the renewable alliance, while to restore market competitiveness that the incumbents lost during the suspension of nuclear power plants.

\section{Discussion}

Why have the landscape pressures, including the Fukushima nuclear disaster been incapable of creating a transition pathway that beyond the transformation, despite the change in public interpretation and the implementation of a feed-in-tariff that would change market competition

\footnotetext{
8 “Renewable energy: Barriers to diffusion,” Nikkei Shinbun March 8, 2014 (in Japanese)

9 A remark by Katsuhiko Naito, a former official of the Japanese Ministry of the Environment at the renewable energy seminar at Kyoto University on October 13, 2015.
} 
between incumbents and renewable producers?

One possible answer is more than fifty years of the LDP's reign in the government office that have sought for energy independency and energy security for economic growth. Encountered with the oil crises, the LDP-led government has exercised its power to direct METI to support nuclear power, and to encourage incumbent electric power companies to develop new nuclear power plants. Capitalized on the financial rents gained from the regionally monopoly, incumbent electric power companies have also exercised their power over the LDP and METI to keep the policy environment stable so that they can profit from infrastructure investments that require long gestation periods. By satisfying demands for a stable energy supply from industry, and by mobilizing media to condition society away from worries about nuclear safety and demands for unbundling the regionally monopolized power supply system, they have gained a wider support and better reputation to nuclear power and the nuclear alliance from the public, embedding deeply in the society, which have increased political influence.

Thus its long-term reign in the government office makes it extremely difficult for renewable energy producers and IPPs to create an alliance with other innovative powers and actors with different priorities, not to mention to do it with transformative power [50]. Except of a feed-in-tariff, the DPJ-led government did not have a clear transition storyline that could shift the current system toward a sustainable pathway when it came to the government office. This forced the government to spend huge amount of time and political resources to gain wider consensus for the energy plan among influential stakeholders whose opinions had been divided into two extremes after the Fukushima nuclear disaster, Coupled with the declining support, this made the DPJ-led cabinet indecisive on the new integrated strategic plan, while enabled the nuclear alliance to regain the power, effectively blocking the empowerment of renewable alliance and the transition of electricity system to go beyond the transformation pathway when the LDP-led government came back to the office.

Long-term reign also weakened positive feedback effects and increased negative ones of the feed-in-tariff. On the one hand, the feed-in-tariff emerged large renewable developers and directed them to initiate large solar and wind parks that was expected a 74 percent of rate of return [51]. Most of them used solar modules and wind turbines that were manufactured by foreign companies or in foreign countries by Japanese companies that did not generate employment in domestic factories. This was in part due to Japanese manufactures' strategies that sought for high-end markets, but to the LDP-led government's policy to restrict deployment of renewable energy in the early 2000s. On the other hand, the feed-in-tariff that was favorable to large renewable producers generated strong negative feedback effects. These developers tended to be outsider that had no link to or stakes in the local society and economy. Unlike local developers such as small business, 
cooperatives, municipalities and farmer, they captured a majority of the financial benefits, not spreading out the benefits of the policy widely through society. Local stakeholders interpreted them as mere local resource exploiters and imposers of burdens. This interpretation provoked local protests over land, making renewable developers and development unpopular. The feed-in-tariff resulted in smaller positive than negative feedback effects, failing to empower the renewable alliance.

Nonetheless, the current electricity system is increasingly destabilized and the nuclear alliance is gradually disentangled as the cost of keeping the current electricity system intact turned out to be too enormous even for the nuclear alliance to burden as time passes on. Few nuclear power plants have been passed the safety review of the new Nuclear Regulation Authority, some of which were decided suspension by the court. Candidates who opposed to the reopening of nuclear power plants won the governors' election in two prefectures whereby nuclear power plants are located. Declining profits and increasing compensation to victims and decommissioning of nuclear reactors make the restructure of the TEPCO unavoidable, and fuelling angers of IPPs and taxpayers against METI and TEPCO that seek for pushing this burden to them [52]. If the angers intensify pressure for legal separation of the incumbent electric power companies, current electricity system would be shifted beyond the transformation pathway, as it would provide less financial resources for the nuclear alliance to exercise political influence against the renewable alliance.

\section{Conclusions}

This paper explores how the temporal dimension have influenced market competition, power and interpretation, and the dynamics of electricity systems in a welfare state in the end, when faced with landscape pressures and emergence of niche innovations, taking a case of Japan. Besides introducing a new typology of power relation for analyzing the dynamics of 'power to change' and 'power to maintain' [18], we showed that transition research on infrasystems in welfare states requires paying attention to the length of period that actors possess and exercise power.

Welfare states have cumulatively made large investment in institutional settings that support a particular type of infrasystem. This enables constitutive power to create an alliance to reinforce the current infrasystem, making it challenging for innovative power to develop, creating an alternative alliance to move it toward the sustainable pathway. The longer constitutive power possesses and exercises power to keep the current infrasystem, the deeper the infrasystem can be embedded into the society and the more likely it becomes to be economically self-sustaining. Monopoly in service provision gives financial resources to capture the regulators and politicians and to tame media to share ideas, norms and discourses that are in align with them, and even capitalize on landscape pressure to reinforce the current infrasystem. 
In addition, long-term reign of constitutional power can reduce feedback effects in policy instruments and institutional reform. This further weakens driving force for transition to sustainability.

This implies that innovative power should not only advance technological innovation, but also take advantage of landscape pressures when they destabilize the current infrasystem. This includes: creation of an alliance with actors with different priorities and with transformative power; implementation of policy instruments and institutional reform that distribute benefits of transition widely to bring beneficiaries in the alliance; and gain market competitiveness and keep enhancing power relations against constitutive power longer time to prevent swing the transition back. To take advantage, it should prepare a storyline of transition that can be widely accepted under the dominance of constitutive power. While challenging, this is a way to generate a larger positive feedback effects that enable innovative power to be empowered and to involve transformative power to address institutions that support unsustainable pathway. It remains a future challenge to elucidate how to make it.

\section{References}

[1] Dasgupta, P., Human Well-Being and the Natural Environment, Oxford: Oxford University Press (2002).

[2] Frantzeskaki, N. and Loorbach, D., Towards governing infrasystem transitions’ Reinforcing lock-in or facilitating change?, Technological Forecasting \& Social Change 77 (2010) 1292-1301.

[3] Verbong, G.P.J. and Geels, F.W., The ongoing energy transition: Lessons from a socio-technical, multi-level analysis of the Dutch electricity system (1960-2004), Energy Policy 35 (2007) 1025-1037.

[4] Geels, F.W. and J.W. Schot, Typology of sociotechnical transition pathways, Research in Policy 36 (3) (2007) 399-417.

[5] Verbong G.P.J. and Loorbach, D., Introduction, in Verbong G.P.J. and Loorbach, D. Governing the Energy Transition: Reality, Illusion or Necessity? Routledge, Oxon (2012), 1-23.

[6] Smith, A. and Raven R., What is protective space? Reconsidering niches in transition to sustainability, Research Policy 41 (6) (2012) 106-19.

[7] Loorbach, D., Frantzeskaki, N. and Thissen. W., Introduction to the special section: Infrastructures and transitions, Technological Forecasting \& Social Change 77 (2010) 1195-1202.

[8] Frantzeskaki, N. and de Haan, H., Transitions: Two steps from theory to policy, Futures 41 (2009) 593-606. 
[9] Geels, F.W., Technological Transitions and System Innovations: A Co-evolutionary and Socio-technical Analysis, Edward Elgar, Cheltenhum (2005).

[10] Verbong, G.P.J. and Geels, F.W., Exploring sustainability transitions in the electricity sector with socio-technical pathways, Technological Forecasting \& Social Change 77 (2010) 1214-21.

[11] Rock, M.T. et al., A hard slog, not a leap frog: Globalization and sustainability transitions in developing Asia, Technological Forecasting \& Social Change 76 (2009) 241-54.

[12] Sovacool, B.K.. How long will it take? Conceptualizing the temporal dynamics of energy transitions, Energy Research \& Social Science 13 (2016) 202-15.

[13] Van Rooijen, S.N.M., Van Wees, M.T., Green electricity policies in the Netherlands: An analysis of policy decisions, Energy Policy 34 (2006) 60-71.

[14] Foxon, T.J., Hammond, G.P. and Pearson P.J.G., Developing transition pathways for a low carbon electricity system in the UK, Technological Forecasting \& Social Change 77 (2010) 1203-13.

[15] Angel, D. and Rock, M.T., Environmental rationalities and the development state in East Asia: Prospects for sustainability transition, Technological Forecasting \& Social Change 76 (2009) 229-40.

[16] Gioia, D.A. and Pitre, E., Multiparadigm perspectives on theory building, Academy of Management Review 15 (1990) 584-602.

[17] Avelino, F. and Rotmans, J., Power in transition: An interdisciplinary framework to study power in relation to structural change, European Journal of Social Theory 12 (4) (2009), 543-69.

[18] Avelino, F. and Rotmans, J. A dynamic conceptualization of power for sustainability research, Journal of Cleaner Production 19 (2011) 796-804.

[19] Mori, A. Conclusion: Advancing environmental policy integration, in Mori A. (ed.) Environmental Policy Integration: Reform of the Policy Decision Making Process and Implementation in Transport Sector in Europe and Japan, Minerva Shobo, Kyoto (2013) 255-67 (in Japanese).

[20] Lockwood, M. The politics of dynamics of green transformations: Feedback effects and institutional context, in Scoones, I., M. Leach and P. Newell (eds.) The Politics of Green Transformation, Routledge, Oxon (2015) 86-101.

[21] Rosman R. et al., Discursive regime dynamics in the Dutch energy transition, Environmental Innovation and Societal Transitions 13 (2014) 45-59.

[22] Research Organization for Information Science \& Technology, Sunshine and moonlight programs (2004) 
http://www.rist.or.jp/atomica/data/dat_detail.php?Title_No=01-05-02-01, accessed on December 1, 2014.

[23] Agency for Natural Resources and Energy, Annual Report on Energy, FY 2013 (2014a) (in Japanese), http://www.enecho.meti.go.jp/about/whitepaper/2014pdf, accessed on July 28, 2014.

[24] Agency for Natural Resources and Energy, State of art and challenges on renewable energy (2014b) (in Japanese), http://www.meti.go.jp/committee/sougouenergy/shoene_shinene/shin_ene/pdf/001_03_00.pdf, accessed on July 24, 2014.

[25] Expert Committee on Electricity System Reform, Report from the Expert Committee on Electricity System Reform

http://www.meti.go.jp/committee/sougouenergy/sougou/denryoku_system_kaikaku/pdf/report_0 02_01.pdf, accessed on October 30, 2015.

[26] Institute of Energy Economics Japan (IEEJ), Handbook of Energy and Economic Statistics in Japan, Tokyo: Energy Conservation Center (2013).

[27] Mori, A., Green growth and low carbon development in East Asia: Achievements and challenges, in Yoshida F. and A. Mori (eds.), Green Growth and Low Carbon Development in East Asia, Oxon: Routledge (2015) 278-304.

[28] Ministry of Economy, Trade and Industry, Prediction of Long-term Demand and Supply of Electricity (in

Japanese),

http://www.meti.go.jp/press/2015/07/20150716004/20150716004_2.pdf, accessed on November 4, 2015.

[29] International Energy Agency, The Power Transformation, International Energy Agency, Paris, (2014).

[30] Yasuda, Y., Deployment of renewable energy and technological challenges of electricity system, in Oshima K. and Takahashi H. (ed.) Distributed Energy System, Nihon Hyoronsha, Tokyo (2016) 115-46 (in Japanese).

[31] Takahashi, H., Market Liberalization of Electric Utilities: Why Do We Need Unbundling of Power Grid After 3.11?, Nihon Keizai Shinbun Shuppansha, Tokyo (2011) (in Japanese).

[32] Miyamoto, K. Environmental Economics, $2^{\text {nd }}$ edition, Iwanami Shoten, Tokyo (2007) (in Japanese).

[33] Hasegawa, K., Toward a Nuclear phase-out Society: Greening Electricity, Iwanami Shinsho, Tokyo (2011).

[34] National Policy Unit, Report on the Electricity Cost Inspection Committee (2011) (in Japanese), 
http://www.cas.go.jp/jp/seisaku/npu/policy09/pdf/20111221/hokoku_kosutohikaku.pdf, accessed on November 13, 2015.

[35] Ministry of Economy, Trade and Industry, The New National Energy Strategy (2006) (in Japanese), http://www.rist.or.jp/atomica/data/dat_detail.php?Title_No=01-09-09-09, accessed on November 13, 2015.

[36] Kikkawa, T., Electricity Reform: Historical Transformation of Energy Policy, Kodansha, Tokyo (2012) (in Japanese).

[37] Honma, R. Nuclear Power Propaganda, Iwanami Shinsho, Tokyo (2016) (in Japanese).

[38] Cabinet Office, Abstract of the results on the Special Opinion Survey on Nuclear Power (2009) http://survey.gov-online.go.jp/tokubetu/h21/h21-genshi.html, accessed on December 20, 2016 (in Japanese).

[39] Takahashi, H. Reform of electricity system in progress: toward stable supply under the distributed electricity system, in Oshima K. and Takahashi H. (ed.) Distributed Energy System, Nihon Hyoronsha, Tokyo (2016) 215-37 (in Japanese).

[40] Oshima, K., Cost of Nuclear Power: A Perspective for Energy Transformation, Iwanami Shinsho, Tokyo (2011) (in Japanese).

[41] Tasaka, H., Three ways to realize the 'Nuclear Regulation Authority' that people wish to establish, Nikkei Business On-line, August $17 \quad 2012 \quad$ (2012), http://business.nikkeibp.co.jp/article/report/20120815/235569/ accessed on November 16, 2015.

[42] Ikeda, N., 'Non-performing asset that amount to JPY 11 trillion' blocks solving problem of spent nuclear fuel, News Week Japanese Edition, February 112015 (2015) (in Japanese), http://www.newsweekjapan.jp/column/ikeda/2015/02/11.php (last accessed on November 14, 2015).

[43] Ministry of Economy, Trade and Industry, State of art and challenges of the institutions for promoting renewable energy (2015) (in Japanese), http://www.meti.go.jp/committee/sougouenergy/kihonseisaku/saisei_kanou/pdf/001_02_00.pd f (last accessed on November 13, 2015).

[44] Yamaoka, J., Japan's Electricity War: History of Struggles over Resources, Interests and Nuclear Power, Soushisha, Tokyo (2015) (in Japanese).

[45] Agency for Natural Resources and Energy, About renewable energy (2014c) (in Japanese), http://www.enecho.meti.go.jp/category/saving_and_new/saiene/kaitori/kakaku.html, accessed on August 1, 2014.

[46] Agency for Natural Resources and Energy, Settlement of FY2015 Purchase Prices and FY2015 Surcharge Rates under the Feed-in Tariff Scheme for Renewable Energy (2015) (in Japanese), http://www.meti.go.jp/english/press/2015/0319_01.html, accessed on November 13, 2015. 
[47] Agency for Natural Resources and Energy, Agenda for the Amount of Renewable Energy (2014d) (in Japanese), http://www.meti.go.jp/committee/sougouenergy/shoene_shinene/shin_ene/pdf/003_04_00.pdf, accessed on December 1, 2014.

[48] Hatta, T., How to Advance Electricity System Transformation, Nihon Keizai Simbun Shuppansha, Tokyo (2012) (in Japanese).

[49] Yamaga, K., Emergence of 'renewable quota' and crisis of feed-in-tariff, Nikkei Business Online January 7, $2015 \quad$ (in http://business.nikkeibp.co.jp/article/report/20140328/261942/?rt=nocnt, accessed on January 31, 2015.

[50] Schreurs, M.A., Environmental Politics in Japan, Germany, and the United States, Cambridge University Press, Cambridge (2002).

[51] Friedman, B, R. Margolis and J. Seel, Comparing photovoltaic (PV) costs and deployment drivers in the Japanese and U.S. residential and commercial markets, NREL/TP-6A20-60360, National Renewable Energy Laboratory (2016).

[52] Ikeda N. JPY 21.5 trillion for compensation, decommissioning and decontamination expense is too much, JB Press December 16, 2016 (2016), http://jbpress.ismedia.jp/articles/-/48684, accessed on December 19, 2016.

[53] Duffield, J.S. and Woodall, B., Japan's new basic energy plan, Energy Policy 39 (2011) 3741-9.

[54] Pickett, S.E., Japan's nuclear energy policy: From firm commitment to difficult dilemma addressing growing stocks of plutonium, program delays, domestic opposition and international pressure, Energy Policy 30 (2002) 1337-55. 